\title{
CAVITY PROBLEMS AND THEIR MANAGEMENT IN POST MODIFIED RADICAL MASTOIDECTOMY IN PEDIATRIC POPULATION - A CLINICAL AUDIT
}

\author{
Habib Ur Rahman Afridi, Bakht Zada, Fazal-I-Wahid, Hamid Mashreqi
}

Lady Reading Hospital MTI, Peshawar Pakistan

\begin{abstract}
Objective: To find out the intensity and frequency of cavity problems of persistent and recurrent ear discharge in young children and their management in post Modified Radical Mastoidectomy (MRM).

Study Design: Cross sectional study.

Place and Duration of Study: Department of ENT Head \& Neck Surgery, Lady Reading Hospital MTI Peshawar Pakistan, from Jan 2015 to Dec 2019.

Methodology: Fifty-four patients with cavity problems of persistent and recurrent ear discharge needing treatment were included in the study (out of the total patients 234 operated upon). Patients were followed up for one year for any discharge of the mastoid cavity. Patients of both gender of age 15 years or younger were included in the study.

Results: In this study the cavity problems were found in $23.1 \%$ (54 out of 234) of the post modified radical mastoidectomy in pediatric population. There were no surgery related problems in $61.1 \%$ patients. In $38.9 \%$ (21 out of 54 ) percent patients repeat mastoidectomy was performed. Where as in $37 \%$ (20 out of 54) excision of granulation and conservative management was sufficient in curing the disease. High facial ridge was found to be the most common cause of persistent/recurrent discharge 9 out of $54(16.7 \%)$.

The independent variables (Indications for repeat mastoidectomy, Factors causing discharge, Surgery related problems) support the dependent variable treatment outcome. The sig/ $p$-value was zero therefore the result was significant.

Conclusion: In post Modified Radical Mastoidectomy, the cavity can be dry provided meticulous care is given to complete exenteration of disease from all areas, properly lowered facial ridge and optimum sized meatoplasty.
\end{abstract}

Keywords: Atticoantral disease, Cholesteatoma, Modified radical mastoidectomy.

How to Cite This Article: Afridi HUR, Zada B, Wahid F, Mashreqi H. Cavity Problems and Their Management in Post Modified Radical Mastoidectomy in Pediatric Population - A Clinical Audit. Pak Armed Forces Med J 2021; 71 (Suppl-3): S542-545. $\quad$ Doi: https://doi.org/10.51253/pafmj.v1i1.7930

This is an Open Access article distributed under the terms of the Creative Commons Attribution License (https://creativecommons.org/licenses/by-nc/4.0/), which permits unrestricted use, distribution, and reproduction in any medium, provided the original work is properly cited.

\section{INTRODUCTION}

CSOM is a common disease in ENT practice both in adults as well as in children. It is broadly divided into two, mucosal and squamous types. Squamous type of CSOM is commonly associated with cholesteatoma and granulation tissues. ${ }^{1}$ Modified radical mastoidectomy is the surgical procedure in whichdisease is cleared from mastoid air cell system and at the same time hearing rehabilitation is attempted. This is a canal wall down (CWD) procedurewhere mastoid antrum is communicated to external auditory canal. ${ }^{2}$ This procedure is quite commonly performed in pediatric otology practice. $^{2}$

Squamous CSOM presenting with cholesteatoma or granulation tissues needs surgical management. Delay in the operation to create space in the ear canal and mastoid can eventually leads to the emergence of complications such as hearing impairment, disturbance in balanceand evenfacial paralysis. ${ }^{3}$ Many studies have

Correspondence: Dr Bakht Zada, Associate Professor, Dept of ENT, Head \& Neck Surgery, Lady Reading Hospital MTI, Peshawar Pakistan documented that children are affected more by cholesteatoma in their ears. The smelly discharge from ear is the main symptom of this problem. Worldwide 9 persons in each 100,000 individuals are living with this condition. However, number of cases undergoing surgery is quite few. ${ }^{4}$

Children undergoing Modified Radical Mastoidectomy (MRM)are usually cured and get their ears dry. However some children reported post-operative cavity problems. ${ }^{5}$ About $20-25 \%$ children reported post MRM cavity problems especially persistent or recurrent discharge. ${ }^{6}$

Properly performed MRM allows tremendous ease in visualization of mastoid cavity and help in selfcleansing of debris. Also thorough inspection is done through meatusin the follow up period in the outpatient setting and second look surgery is usually not required. ${ }^{7}$

On the other hand, CWD mastoidectomies are associated with some disadvantages. The most common problems of the procedure are accumulation of keratin debris and need for frequent cleaning, higher 
susceptibility to infection with water exposure, risk of sudden dizziness associated with change of temperature in the external auditory canal and hearing aid discomfort. ${ }^{8}$

Sometimes very large mastoid cavity formed after clearing the disease is troubling the patient and cavity obliteration or even redo surgery is needed in such large mastoid cavities with inadequate meatoplasty.9,10

Due to insufficient evidence in local literature we conducted this study to generate evidence based knowledge in this important segment of pediatric otological practice. This study will help to increase the level of understanding of our local practitioners and shall enable them to manage children presenting with squamous type of CSOM more efficiently.

\section{METHODOLOGY}

This study was conducted at the department of ENT Head \& Neck Surgery at Lady Reading Hospital MTI, Peshawar Pakistan, from January 2015 to December 2019. Sample size was calculated by WHO sample size calculator by using study of Khan et al. ${ }^{15}$

After approval from the hospital ethics review committee and written informed consent from relatives of potential participants, patients were entered according to inclusion and exclusion criteria.

Inclusion Criteria: Children of age 15 and below with cavity problems of persistent and recurrent ear dischargeneeded treatment.

Exlusion Criteria: Those patients who were lost to follow up during study.

Non probability consecutive sampling technique was used to collect the data. A detail history especially of ear discharge and clinical examination including otoscopy, examination under microscope was carried out in all cases. High resolution CT scan was obtained to confirm the findings. All surgeries were performed by qualified ENT consultants.

Out of the total 234 patients operated for modified radical mastoidectomy 54 had cavity problems. All patients presented to ENT Unit through OPD (38), emergency (7), Pediatric unit (3) and referred from other hospitals (6). All patients were diagnosed as CSOM atticoantral disease by Otoscopy and Microscopy.

After surgery the patients were followed and mastoid cavities inspected after wound healing initially at 1 month and later after interval of 3, 6 and 12 months. The patients were inspected by otoendoscopy and microscopy. Mastoid cavities were especially examined for discharge, debris and persistence of disease i.e., choles- teatoma or granulation tissues. The data was collected on a pre-structured proforma. SPSS-22 was used for data analysis. Mean \pm SD was calculated for numerical variables like age. Frequencies and percentages were calculated for categorical variables like gender, discharge and recurrence.

\section{RESULTS}

There were total 234 patients operated for active squamous disease and cholesteatoma with modified radical mastoidectomy. Cavity problems were found in 54 patients that come to about $23.1 \%$.

There were $53.7 \%$ male and $46.3 \%$ female. Age wise $53.7 \%$ were between 11 and 15 years, $35.2 \%$ were between 6 and 10 years and $11.1 \%$ were $<5$ years.

All the patients presented themselves to the ENT department through the following channels: OPD $(70.4 \%)$, emergency $(13 \%)$, pediatric unit $(5.6 \%)$ and referred from other hospitals $(11.1 \%)$. Factors causing discharge were reported as follows: surgery related problems $(38.9 \%)$, granulation tissue formation (22.2\%) infection in the nasopharynx $(13 \%)$, impacted debris/ wax $(13 \%)$, auditus block (7.4\%) and residual cholesteatoma $(5.6 \%)$.

There were no surgery related problems in $61.1 \%$. For remaining causes were; high facial ridge (22.2\%), improper meatoplasty $(9.3 \%)$, not properly saucerized mastoid cavity $(3.7 \%)$ and extremely large mastoid cavity $(3.7 \%)$.

Table-I: Surgery related problems.

\begin{tabular}{l|c|c}
\hline & Frequency & Percentage \\
\hline High facial ridge & 12 & 22.2 \\
\hline Improper meatoplasty & 5 & 9.3 \\
\hline $\begin{array}{l}\text { Not properly saucerized } \\
\text { mastoid cavity }\end{array}$ & 2 & 3.7 \\
\hline Extremely large mastoid cavity & 2 & 3.7 \\
\hline None & 33 & 61.1 \\
\hline Total & 54 & 100 \\
\hline Table-II:Indication for repeat mastoidectomy. \\
\hline \multicolumn{2}{|c}{ Frequency } & Percentage \\
\hline High facial ridge & 9 & 16.7 \\
\hline $\begin{array}{l}\text { Recurrent/residual } \\
\text { cholesteatoma }\end{array}$ & 3 & 5.6 \\
\hline Improper meatoplasty & 4 & 7.4 \\
\hline Granulations tissue formation & 3 & 5.6 \\
\hline Auditus block & 2 & 3.7 \\
\hline None & 33 & 61.1 \\
\hline Total & 54 & 100 \\
\hline Table-III: Treatment outcome. & Frequency & Percentage \\
\hline \multicolumn{2}{|c|}{} \\
\hline Repeat Mastoidectmy & 21 & 38.9 \\
\hline Granulations Tissues Excision & 20 & 37 \\
\hline Treatment Satisfactory & 13 & 24.1 \\
\hline Total & 54 & 100 \\
\hline
\end{tabular}


Indications for repeat mastoidectomy were found to be as follows: There were none in $61.1 \%$ patients indicating that repeat mastoidectomy was not needed. For the remaining high facial ridge (16.7\%), improper meatoplasty $(7.4 \%)$, recurrent/residual cholesteatoma (5.6\%), Granulations tissue formation (5.6\%) and Auditus block (3.7\%).

Treatment outcome was satisfactory in $24.1 \%$ cases. Rest was as follows: repeat mastoidectmy $(38.9 \%)$ and granulations tissues excision (37\%).

In the model summary the value of $\mathrm{R}(0.905), \mathrm{R} 2$ (0.819) and adjusted R2 (0.809) indicate that the independent variables support the dependent variable up to the extent of $90 \%, 81.9 \%$ and $80.9 \%$. The Durbin Watson value of 0.729 indicate that there is a strong positive relationship between independent variables (Indications for repeat mastoidectomy, Factors causing discharge, Surgery related problems) and dependent variable of treatment outcome. The zero sig or $p$-value indicates that the result is significant.
Paediatric MRM is a difficult procedure because of highly pneumatized mastoid ear cell system with extensive cholesteatoma spread. Cholesteatoma is more aggressive in children than in adults, spread very fast and becomes worse by superinfection. ${ }^{8}$ In thissituation there is high chance of leaving behind the cholesteatoma which may be the reason of recurrence or residual disease. ${ }^{11}$

In this study the cavity problems were found in $23.1 \%$. Our findings correlate with findings by some other studied in which the author mentioned the incidence $20-25 \% .{ }^{13}$ Kos etal, ${ }^{14}$ reported $30 \%$ cavity problems and another local study by Khan et al, 15 confirmed that the incidence of cavity problem is $26.6 \%$.In $38.9 \%$ patient repeat mastoidectmywas also mentioned by some other authors. ${ }^{16}$ The age group most affected in our study was $11-15$ years $(53.7 \%)$ followed by $6-10$ years $(35.2 \%)$. These observations are consistent with those of the studies of Vartianen, ${ }^{17}$ and Rajan et al. ${ }^{18}$

Post operatively mastoid cavity is usually healed

Table-IV: Statistics.

\begin{tabular}{l|c|c|c|c|c|c|c|c}
\hline \multicolumn{2}{l|}{} & Gender & Age & $\begin{array}{c}\text { Total Patients Presented } \\
\text { to ENT Unit Through }\end{array}$ & $\begin{array}{c}\text { Factors Causing } \\
\text { Discharge }\end{array}$ & $\begin{array}{c}\text { Surgery Related } \\
\text { Problems }\end{array}$ & $\begin{array}{c}\text { Indications for Repeat } \\
\text { Mastoidectomy }\end{array}$ & $\begin{array}{c}\text { Treatment } \\
\text { Outcome }\end{array}$ \\
\hline \multirow{2}{*}{$\mathrm{N}$} & Valid & 54 & 54 & 54 & 54 & 54 & 54 & 54 \\
\cline { 2 - 8 } & Missing & 0 & 0 & 0 & 0 & 0 & 0 \\
\hline Mean & 1.4630 & 2.4259 & 1.5741 & 2.5926 & 3.7222 & 4.5741 \\
\hline Median & 1.0000 & 3.0000 & 1.0000 & 2.0000 & 5.0000 & 6.0000 & 2.0000 \\
\hline Mode & 1.00 & 3.00 & 1.00 & 1.00 & 5.00 & 6.00 \\
\hline \multicolumn{2}{l|l}{ Std. Deviation } & 0.50331 & 0.68960 & 1.02058 & 1.63128 & 1.73114 & 2.00567 \\
\hline
\end{tabular}

Table-V: Model Summaryb.

\begin{tabular}{c|c|c|c|c|c|c|c|c|c|c|c|c}
\multirow{2}{*}{ Model } & \multirow{R}{*}{} & \multirow{2}{*}{$\begin{array}{c}\mathbf{R} \\
\text { Square }\end{array}$} & \multirow{2}{*}{$\begin{array}{c}\text { Adjusted } \\
\text { R Square }\end{array}$} & $\begin{array}{c}\text { Std. Error } \\
\text { of the } \\
\text { Estimate }\end{array}$ & $\begin{array}{c}\text { R Square } \\
\text { Change }\end{array}$ & $\begin{array}{c}\text { F } \\
\text { Change }\end{array}$ & df1 & df2 & $\begin{array}{c}\text { Sig. F } \\
\text { Change }\end{array}$ & $\begin{array}{c}\text { Durbin- } \\
\text { Watson }\end{array}$ & $\begin{array}{c}\text { Sig } \\
\text { value } / p \text { - } \\
\text { value }\end{array}$ \\
\hline 1 & $0.905 a$ & 0.819 & 0.809 & 0.34429 & 0.819 & 75.611 & 3 & 50 & 0.000 & 0.729 & $0.000 \mathrm{~b}$ \\
\hline
\end{tabular}

a: Predictors: (Constant), Indications for repeat mastoidectomy, Factors causing discharge, Surgery related problems, b: Dependent Variable:

Treatment outcome

\section{DISCUSSION}

MRM is the procedure to resolve problems of inner ear, by eliminating the disease and rehabilitating the hearing mechanism. ${ }^{11}$ This is the procedure of choice in terms of outcomes. But certain important problems are associated with the procedure especially when not done properly. This can lead to persistent discharge.These include not eradicating the disease from the difficult areas like sinus tympani, not properly lowering down of facial ridge due to fear of injury to the nerve and narrow meatoplasty. ${ }^{12}$ In most of the cases the cavity is properly managed postoperatively and self-cleansing is easy not allowing debris to accumulate. and epithelialization occurs in few weeks' time. ${ }^{19}$ Nearly $20 \%$ of patients experience the cavity issue in children. In children, $75 \%$ experience otitis media. It has been found that despite the fact that the problem is related to children but most of the patients came through OPD (70.4\%). There were no surgery related problems in $61.1 \%$ patients. Treatment outcome was satisfactory in $24.1 \%$ cases. The independent variables (Indications for repeat mastoidectmy, Factors causing discharge, Surgery related problems) support the dependent variable treatment outcome. The sig $/ p$-value was zero therefore the result was significant.

The result concludes that in post modified radical mastoidectomy in pediatric population $24.1 \%$ patients 
the treatment was satisfactory. For the rest repeat mastoidectomy was done in most of the patients.

\section{ACKNOWLEDGEMENT}

The authors acknowledge the work of IT expert Sajid Ali for compiling this manuscript.

\section{LIMITATION OF STUDY}

The study follow up period is not sufficient as the occurrence of complications may happen late. In future a big cohort to be followed for longer period is required to get optimum results.

\section{CONCLUSION}

Modified radical mastoidectmy is a surgical procedure with good outcome in terms of eradicating cholesteatoma. The procedure carries the risk of recurrent discharge as a potential problem especially in children. This problem can be eliminated or minimized by giving attention toremoval of the disease from sinus tympani area, properly lowering the facial ridge and making meatoplasty of optimum size. The cavity must be rounded and smoothly contoured with no overhanging ridges and low facial ridge in order to allow migration of epithelium.

\section{Conflict of Interest: None.}

\section{Authors' Contribution}

HURA: Study design and intellectual support, BZ: Data collection and manusript writtting, FW: Data analysis, HM: Literaure review and discussion

\section{REFERENCES}

1. Samadhiya $\mathrm{M}$, Agarwal $\mathrm{H}$, Vaidya S.Outcome of canal wall down mastoidectomy: a retrospective review. Ind J Otolaryngol Head Neck Surg 2020; 72(3): 388-391.

2. Olszewska E, Rutkowska J, Özgirgin N. Consensus-based recommendations on the definition and classification of cholesteatoma. J IntAdv Otol 2015; 11(1): 81-87.

3. Mamikoglu B. Retrograde Mastoidectomy. Otology \&Neurotol 2018; 39(3): 389-392.

4. Conway RM, Sioshansi PC, Howard AL, Babu SC. Perioperative cost evaluation of canal wall down mastoidectomy. Am J Otolaryngol 2020; 41(6): 1027-1033.

5. Islam SS, Siddiquee BH, Kabir AL, Islam MR, Razzak MA. Comparative study of hearing status after modified radical mas- toidectomy with and without reconstruction. Bangl J Otorhinol 2019; 25(1): 41-46.

6. Patar M, Islam T, Sharma K, Goswami A. A Hospital based study on clinical indications, presentations and operative finding of mastoidectomy in children. Inter J Scient Res 2016; 8(10): 46-48.

7. Goyal R, Mourya A, Qureshi S, Sharm S. Modified radical mastoidectomy with type III tympanoplasty: Revisited Indian J Otolaryngol Head Neck Surg 2016; 68(1): 52-55.

8. Kurien G, Greeff K, Gomaa N. Mastoidectomy and mastoid obliteration with autologous bone graft: a quality of life study. J Otolaryngol Head Neck Surg 2013; 23(2): 42-49.

9. Takahashi M, Iwasaki S. A Postimplant cholesteatoma after modified radical mastoidectomy. J Otolaryngol Head Neck Surg 2013; 8(1): 25-31.

10. Romdhane N, Chiboub D, Zoghlami I, Dallegi S, Nefzaoui S, Hriga I, et al. External auditory canal cholesteatoma (EACC). J Tun Orl 2018; 40(1): 73-76.

11. Das S, Dutta M, Panja T, Sinha R. Chronic draining ear and cholesteatoma recidivism: a retrospection from clinical, imaging, and surgical perspectives. Turk Arch Otorhinolaryngol2019; 57(3): 133-139.

12. Kennedy KL, Singh AK. Middle ear cholesteatoma. StatPearls 2020 [Internet] Available at: https://www.ncbi.nlm.nih.gov/ books/NBK448108/

13. Rohlfing ML, Sukys JM, Poe D, Grundfast KM. Bilateral congenital cholesteatoma: a case report and review of the literature.Int J Pediatr Otorhinolaryngol 2018; 107(1): 25-30.

14. Kos MI, Castrillon R, Montandon P, Guyot JP. Anatomic and functional long-term results of canal wall down mastoidectomy. Ann Otol RhinolLaryngol 2004; 113(11): 872-876.

15. Khan AA, Manzoor T, Shah AA, Ayub Z. Evaluation of mastoid cavities after canal wall down mastoidectomy. Pak Armed Forces Med J 2009; 59(3): 295-297.

16. Kumar I, Kumar B. Incidence of cavity problems after open cavity mastoidectomy and perioperative factors involved in the causation of cavity problems: an observational study. Int J Health Clin Res 2020; 3(12): 244-247.

17. Rajan D.A prospective analysis of post mastoidectomy cavity complications. Int J Otorhinolaryngol Head Neck Surg 2019; 5(6): 1566-1569.

18. Vartianen E.Ten year results of canal wall down mastoidectomy for acquired cholestetoma. Auris Nasus Larynx 2001; 27(3): 227229.

19. Baz MR. Effect of cortical mastoidectomy on audiological outcomes in mucosal chronic otitis media. Al-Azhar Int Med J 2020; 1(1): 258-263. 